\title{
KAJIAN KEKERINGAN METEOROLOGIS MENGGUNAKAN STANDARDIZED PRECIPITATION INDEX (SPI) DI PROVINSI JAWA TENGAH
}

\author{
Oleh: \\ Habibah Nurrohmah, Emilya Nurjani \\ Program Studi Geografi dan Ilmu Lingkungan, Fakultas Geografi UGM \\ habibahnurrohmah@gmail.com
}

\begin{abstract}
Abstrak
Kekeringan sering terjadi di Provinsi Jawa Tengah. Kekeringan tersebut dapat dipengaruhi oleh berbagai faktor dan dapat pula memberikan dampak terhadap berbagai aspek. Penelitian ini bertujuan untuk menganalisis distribusi kekeringan di Provinsi Jawa Tengah. Data yang diperlukan adalah data curah hujan bulanan. Data curah hujan tersebut merupakan data hasil pengukuran lapangan tahun 1981-2010 dan dilengkapi oleh data Tropical Rainfall Measuring Mission (TRMM). Metode yang digunakan meliputi metode Standardized Precipitation Index (SPI) dan interpolasi tension spline. Metode SPI digunakan untuk menentukan klasifikasi kekeringan. Hasil pengolahan SPI dipetakan menggunakan interpolasi tension spline. Kekeringan meteorologis di Provinsi Jawa Tengah terjadi setiap tahun (1981-2010). Kekeringan terluas terjadi pada bulan Setember-November 1982 di 96\% wilayah Provinsi Jawa Tengah. Kekeringan ekstrim (golongan amat sangat kering) terluas terjadi pada bulan Setember-November 1997 di 39\% wilayah Provinsi Jawa Tengah dengan pola membulat serta mengelilingi pusat-pusat wilayah normal di sekitar Kabupaten Banjarnegara, Kabupaten Wonogiri, dan Kabupaten Pati.
\end{abstract}

Kata kunci: ENSO, Jawa Tengah, Kekeringan Meteorologis, Pola Tanam, SPI

\begin{abstract}
Drought often occurs in Central Java Province. It can be affected by many factors and may have some impacts on various aspects. This research aims at analyzing the distribution of drought in Central Java Province. The data required in this research include rainfall data. They were gathered from the field measurements conducted in 1981-2010 and equipped with the Tropical Rainfall Measuring Mission (TRMM). The methods consist of Standardized Precipitation Index (SPI) and tension spline interpolation. SPI is used to classify drought. The results of SPI implementation are mapped using tension spline interpolation. Meteorological drought in Central Java Province occurred each year (1981 to 2010). The widest drought occurred in between September and November 1982 in 96\% of Central Java regions. The widest and extreme drought occurred from September to November 1997 in $39 \%$ regions of Central Java Province having a rounded pattern and surrounding the normal areas of Banjarnegara, Wonogiri, and Pati.
\end{abstract}

Keywords: ENSO, Central Java, Meteorological Drought, Cropping, SPI 


\section{PENDAHULUAN}

Kekeringan meteorologis adalah suatu periode ketika curah hujan yang jatuh di suatu wilayah lebih pendek daripada pasokan air klimatologis yang sesungguhnya (Palmer, 1965). Faktor pokok penyebab kekeringan adalah curah hujan dan peningkatan kebutuhan air (Tjasyono, 2004). Input curah hujan sangat sedikit dan bahkan tidak ada ketika kemarau panjang sehingga tidak ada pasokan airtanah dan air permukaan (Rijanta dkk., 2014). Tjasyono juga menjelaskan bahwa terjadinya kekeringan didukung oleh kelembapan nisbi yang rendah, angin kencang, dan suhu yang tinggi.

Data dari Badan Nasional Penanggulangan Bencana (BNPB) menunjukkan bahwa beberapa wilayah di Provinsi Jawa Tengah sering mengalami kekeringan. Kekeringan terparah tahun 2004-2013 telah menyebabkan Kabupaten Grobogan mengalami kerusakan lahan 11.455 hektar (BNPB, 2015). Berbagai kabupaten lain juga sering mengalami kekeringan dengan luas dampak yang bervariasi dan menimbulkan berbagai permasalahan. Selain itu, BNPB (2015) menyebutkan bahwa kekeringan merupakan bencana hidrometeorologis yang sulit dikendalikan dan berada pada urutan ke empat dari bencana yang sering terjadi di Indonesia.

Provinsi Jawa Tengah memiliki pola hujan monsun. Pola hujan monsun tersebut memiliki kaitan erat terhadap El Nino Southern Oscillation (ENSO). ENSO dapat menyebabkan musim hujan datang lebih lambat dan kemarau datang lebih awal (Kirono dan Partridge, 2002). Durasi kemarau yang semakin lama akan mempengaruhi kekeringan dan menimbulkan dampak lebih besar (Nugroho, 2001).

\section{METODE}

Metode yang dipergunakan dalam penelitian ini adalah pengumpulan dan pengujian data, pengolahan dengan Standardized Precipitation Index (SPI), serta pemetaan dengan interpolasi tension spline. Data yang dipergunakan adalah curah hujan bulanan. Data curah hujan diambil dari 49 titik yang berasal dari stasiun hujan milik Badan Meteorologi Klimatologi dan Geofisika (BMKG) serta Dinas Pengelolaan Sumber Daya Air (PSDA) yang tersebar di Provinsi Jawa Tengah. Empat puluh sembilan titik tersebut juga meliputi data Tropical Rainfall Measuring Mission (TRMM) untuk mewakili wilayah yang tidak memiliki stasiun hujan. Data curah hujan tersebut merupakan data bulanan 30 tahun (1981-2010).

Data curah hujan diuji kualitasnya melalui analisis konsistensi dan korelasi. Analisis konsistensi bertujuan untuk mengetahui kesesuaian data hujan di suatu stasiun terhadap data hujan di stasiun sekitarnya pada waktu yang sama. Nilai konsistensi memiliki rentang 0 sampai 1, dimana semakin mendekati satu, kualitas data dianggap semakin konsisten. Uji konsistensi data dilakukan dengan metode double mass curve atau kurva massa ganda. Sementara itu, analisis korelasi bertujuan untuk mengetahui stasiun hujan mana saja yang akan dipakai karena apabila dua stasiun hujan memiliki korelasi yang kuat artinya kondisi datanya relatif homogen sehingga cukup diwakili salah satu stasiun saja. Persamaan korelasi dirumuskan sebagai berikut: 
$\mathrm{R}=\frac{\mathrm{n} \sum \mathrm{XY}-\left(\sum \mathrm{X}\right)\left(\sum \mathrm{Y}\right)}{\sqrt{\left\{\mathrm{n} \sum \mathrm{X}^{2}-\left(\sum \mathrm{X}\right)^{2}\right\}\left\{\mathrm{n} \sum \mathrm{Y}^{2}-\left(\sum \mathrm{Y}\right)^{2}\right\}}}$

dengan keterangan:

$\mathrm{R}=$ koefisien korelasi

$X=$ variabel $A$

$\mathrm{Y}=$ variabel $\mathrm{B}$

Sementara itu, klasifikasi nilai korelasi disajikan pada Tabel 1.

Tabel 1. Klasifikasi Nilai Korelasi

\begin{tabular}{|c|c|}
\hline Nilai Korelasi (R) & Keterangan \\
\hline $0,00-0,199$ & sangat lemah \\
\hline $0,20-0,399$ & Lemah \\
\hline $0,40-0,599$ & Sedang \\
\hline $0,60-0,799$ & Kuat \\
\hline $0,80-1,000$ & sangat kuat \\
\hline
\end{tabular}

Sumber: Sugiyono (2007)

Data curah hujan diolah menjadi nilai SPI menggunakan software SPI. Data SPI kemudian digunakan untuk menentukan kondisi kekeringan. Klasifikasi kekeringan disajikan pada Tabel 2.

Tabel 2. Klasifikasi Kekeringan Berdasarkan Nilai SPI

\begin{tabular}{|c|c|}
\hline Nilai SPI & Klasifikasi Kekeringan \\
\hline$\geq 2,0$ & Amat sangat basah \\
\hline $1,5-1,99$ & Sangat basah \\
\hline $1,0-1,49$ & Basah \\
\hline$(-0,99)-0,99$ & Normal \\
\hline$(-1,0)-(-1,49)$ & Kering \\
\hline$(-1,5)-(-1,99)$ & Sangat kering \\
\hline$\leq(-2)$ & Amat sangat kering \\
\hline
\end{tabular}

Sumber: BMKG (2012); McKee, Doesken, dan Kleist (1993); World

Meteorological Organization (2012)

Dasar perhitungan SPI dilakukan dengan persamaan berikut (Kumar dkk., 2009):

$\mathrm{SPI}=-\left(\mathrm{t}-\frac{\mathrm{c}_{0}+\mathrm{c}_{1} \mathrm{t}+\mathrm{c}_{2} \mathrm{t}^{2}}{1+\mathrm{d}_{1} \mathrm{t}+\mathrm{d}_{2} \mathrm{t}^{2}+\mathrm{d}_{3} \mathrm{t}^{3}}\right)$

$0<\mathrm{H}(\mathrm{x}) \leq$

$\mathrm{SPI}=+\left(\mathrm{t}-\frac{\mathrm{c}_{0}+\mathrm{c}_{1} \mathrm{t}+\mathrm{c}_{2} \mathrm{t}^{2}}{1+\mathrm{d}_{1} \mathrm{t}+\mathrm{d}_{2} \mathrm{t}^{2}+\mathrm{d}_{3} \mathrm{t}^{3}}\right) 0,5<\mathrm{H}(\mathrm{x}) \leq 1$

dengan keterangan:

$\mathrm{t}=\sqrt{\ln \left(1 / \mathrm{H}(\mathrm{x})^{2}\right) 0}<\mathrm{H}(\mathrm{x}) \leq 0,5$

$\left.\mathrm{t}=\sqrt{\ln \left\{1 /(1-\mathrm{H}(\mathrm{x}))^{2}\right.}\right\} 0,5<\mathrm{H}(\mathrm{x}) \leq 1$
$\mathrm{C}_{0}: 2,515517$
$\mathrm{d}_{1}: 1.432788$
$c_{1}: 0.802583$
$\mathrm{d}_{2}: 0.189269$
c2: 0.010328
$\mathrm{d}_{3}: 0.001308$ 
SPI dapat dihitung pada skala waktu 1 bulanan, 2 bulanan, dan maksimal 72 bulanan (World Meteorological Organization, 2012). SPI yang digunakan dalam penelitian ini adalah SPI 3 bulanan. SPI 3 bulanan cocok untuk analisa pertanian karena berkaitan dengan lengas tanah. Selain itu, SPI 3 bulanan juga sesuai untuk estimasi pada tipe hujan musiman (World Meteorological Organization, 2012).

Kekeringan dipetakan dengan software ArcMap 10.3 melalui interpolasi tension spline. Spline dipilih karena menghasilkan interpolasi yang halus sehingga dapat mendekati kondisi alami (Pasaribu dan Haryani, 2012). Jenis spline yang digunakan adalah tipe tension karena memiliki Root Mean Square Error (RMSE) yang lebih kecil daripada tipe regularized. Interpolasi menggunakan metode regularized spline menghasilkan nilai RMSE 0,8907, sementara interpolasi menggunakan metode tension spline menghasilkan nilai RMSE 0,8365 .

\section{HASIL DAN PEMBAHASAN \\ Pengujian Data}

Hasil uji konsistensi menunjukkan bahwa dari 49 titik stasiun yang dipakai, semuanya memiliki konsistensi yang bagus karena nilainya mendekati satu. Nilai konsistensi tertinggi adalah 0,999 yang salah satunya dimiliki oleh Stasiun Bantarkawung. Sementara itu, nilai konsistensi terendah adalah 0,989 yang dimiliki oleh Stasiun Kedung-Sirodad. Hasil uji konsistensi tertinggi dan terendah tersebut dapat dilihat pada Gambar 1 dan Gambar 2.

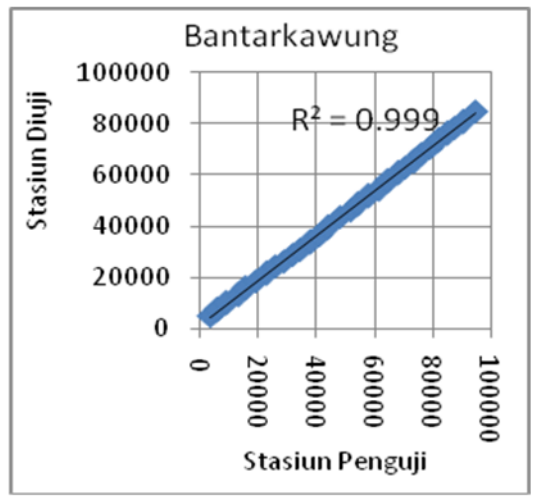

Gambar 1. Grafik Konsistensi Stasiun Bantarkawung

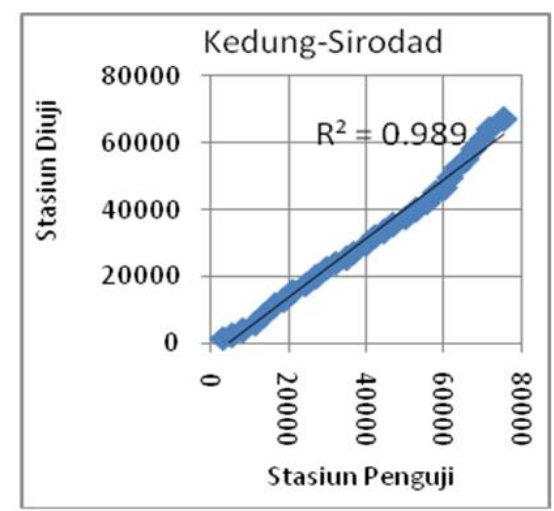

Gambar 2. Grafik Konsistensi Stasiun Kedung-Sirodad 
Selain analisis konsistensi, kualitas data hujan juga diuji melalui analisis korelasi. Hasil dari uji korelasi menunjukkan bahwa dari 49 titik stasiun, semua stasiun tersebut dapat dipakai untuk analisis lanjut. Hal itu disebabkan oleh sebagian besar nilai korelasi berada dibawah 0,8 dengan golongan lemah, sedang, dan kuat. Walau demikian, terdapat pula beberapa titik stasiun yang memiliki korelasi sangat kuat yang nilainya $0,8-1$. Dua stasiun yang memiliki korelasi sangat kuat seharusnya salah satunya tidak dipakai dan cukup diwakili satu stasiun saja karena datanya relatif homogen. Namun setelah dilakukan analisis lebih lanjut, stasiun-stasiun yang memiliki korelasi sangat kuat tersebut berada pada lokasi yang berjauhan. Oleh karena itu, dari 49 stasiun yang ada, semua stasiun dianggap lolos uji korelasi dan dapat dipakai untuk analisis kekeringan pada tahap selanjutnya.

\section{Kekeringan Secara Umum}

Kasus kekeringan di Provinsi Jawa Tengah selalu terjadi setiap tahun (1981-2010). Walau demikian, wilayah yang mengalami kekeringan cenderung berubah-ubah. Luas wilayah terdampak juga mengalami perubahan.

Berdasarkan data 1981-2010, kekeringan terluas di Provinsi Jawa Tengah terjadi pada bulan September-November 1982 dengan luas 32.775,08 km². Kekeringan luas juga terjadi tahun 2006 dan 1994. Luas kekeringan yang memiliki peringkat lima teratas disajikan pada Tabel 3.

Tabel 3. Kekeringan Tiga Bulanan Terluas Tahun 1981-2010 di Provinsi Jawa Tengah

\begin{tabular}{|l|l|l|l|}
\hline No & \multicolumn{1}{|c|}{ Tahun } & \multicolumn{1}{|c|}{ Bulan } & \multicolumn{1}{c|}{ Luas Kekeringan $(\mathrm{km} 2)$} \\
\hline 1 & 1982 & September-November & 32775.08 \\
\hline 2 & 2006 & September-November & 30617.61 \\
\hline 3 & 2006 & Agustus-Oktober & 29721.18 \\
\hline 4 & 1982 & Oktober-Desember & 29115.68 \\
\hline 5 & 1994 & Mei-Juli & 28533.24 \\
\hline
\end{tabular}

\section{Kekeringan September-Desember 1982}

Kekeringan September-November 1982 berada di urutan pertama dalam hal luas wilayah terdampak kekeringan. Sementara itu, kekeringan Oktober-Desember berada di urutan 4. Kekeringan itu menyebabkan hampir seluruh Provinsi Jawa Tengah mengalami kekeringan seperti terlihat pada Gambar 3 dan Gambar 4.

Kekeringan didominasi oleh golongan sangat kering, kemudian diikuti golongan kering dan amat sangat kering. Sebagian besar golongan amat sangat kering tersebar di sisi selatan dan timur Provinsi Jawa Tengah pada September-November. Setelah memasuki Oktober-Desember, wilayah yang tergolong amat sangat kering bergeser ke sisi barat. Berbeda dengan golongan amat sangat kering, golongan sangat kering terdistribusi hampir merata baik pada kedua periode kekeringan tersebut. Sebagian besar golongan kering tersebar di sisi utara dan timur pada September-November. Sementara itu, di bulan Oktober-Desember, golongan kering cenderung membentuk pola bulat dan tersebar merata. 


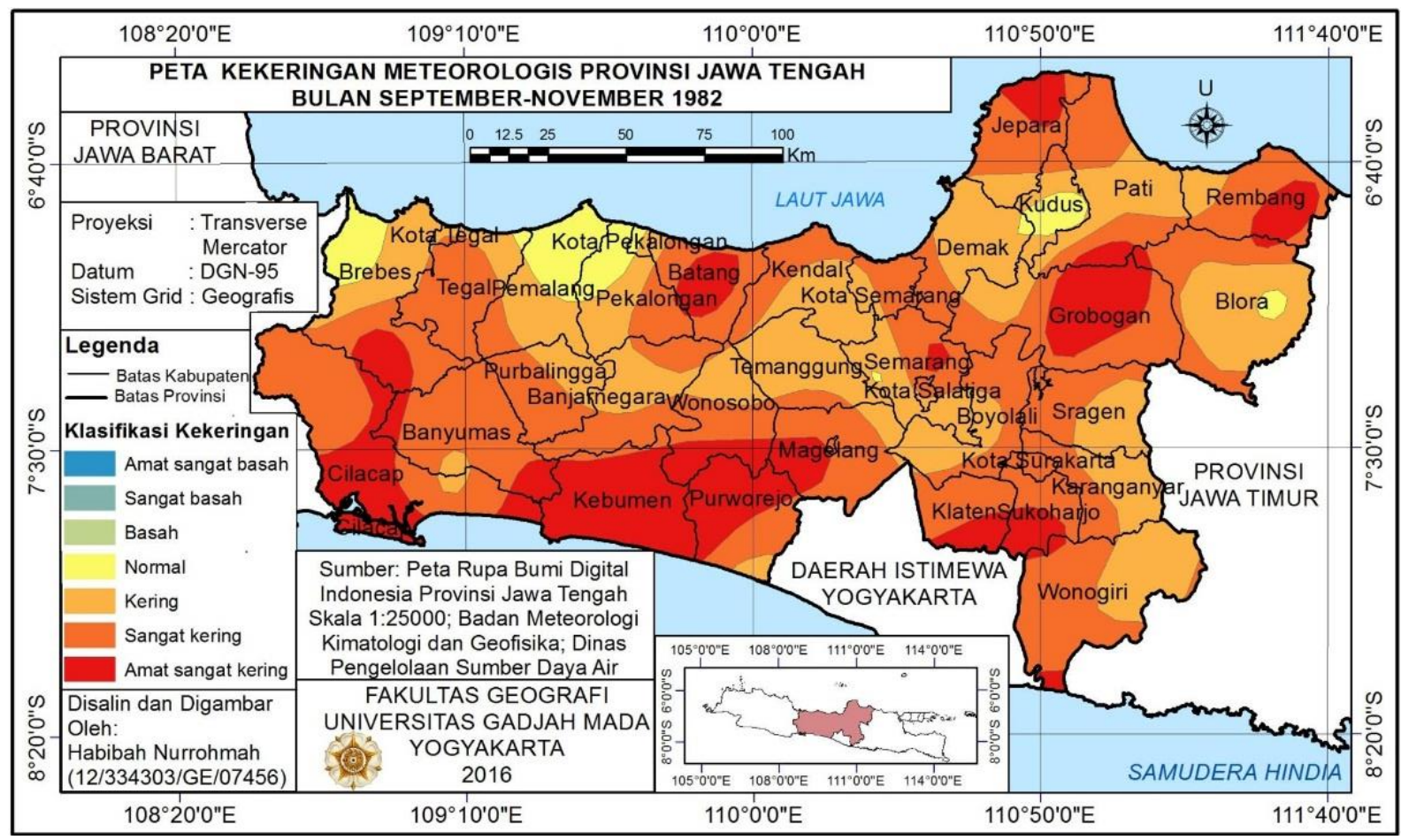

Gambar 3. Peta Kekeringan Meteorologis Provinsi Jawa Tengah Bulan SeptemberNovember 1982

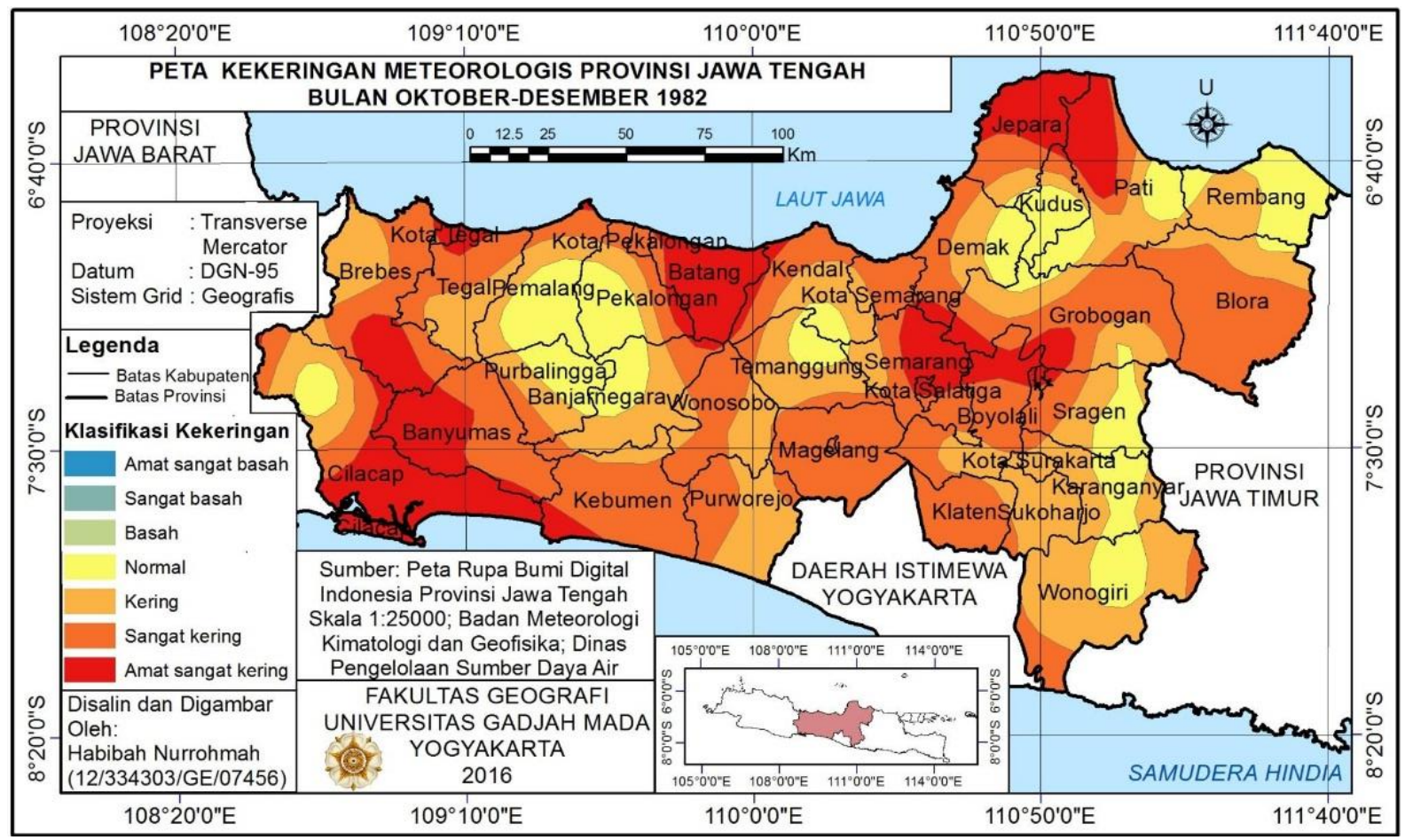

Gambar 4. Peta Kekeringan Meteorologis Provinsi Jawa Tengah Bulan Oktober-Desember 1982 
Kekeringan meteorologis dapat dipengaruhi berbagai faktor lingkungan seperti topografi, jarak terhadap laut, dan bentuklahan. Wilayah yang bertopografi terjal sebagian besar memiliki golongan sangat kering dan kering pada September-November. Golongan amat sangat kering sebagian besar terletak di wilayah bertopografi landai. Sementara itu, pada Oktober-Desember, topografi terjal memiliki golongan kekeringan bervariasi mulai dari kering sampai amat sangat kering. Peta topografi disajikan pada Gambar 5.

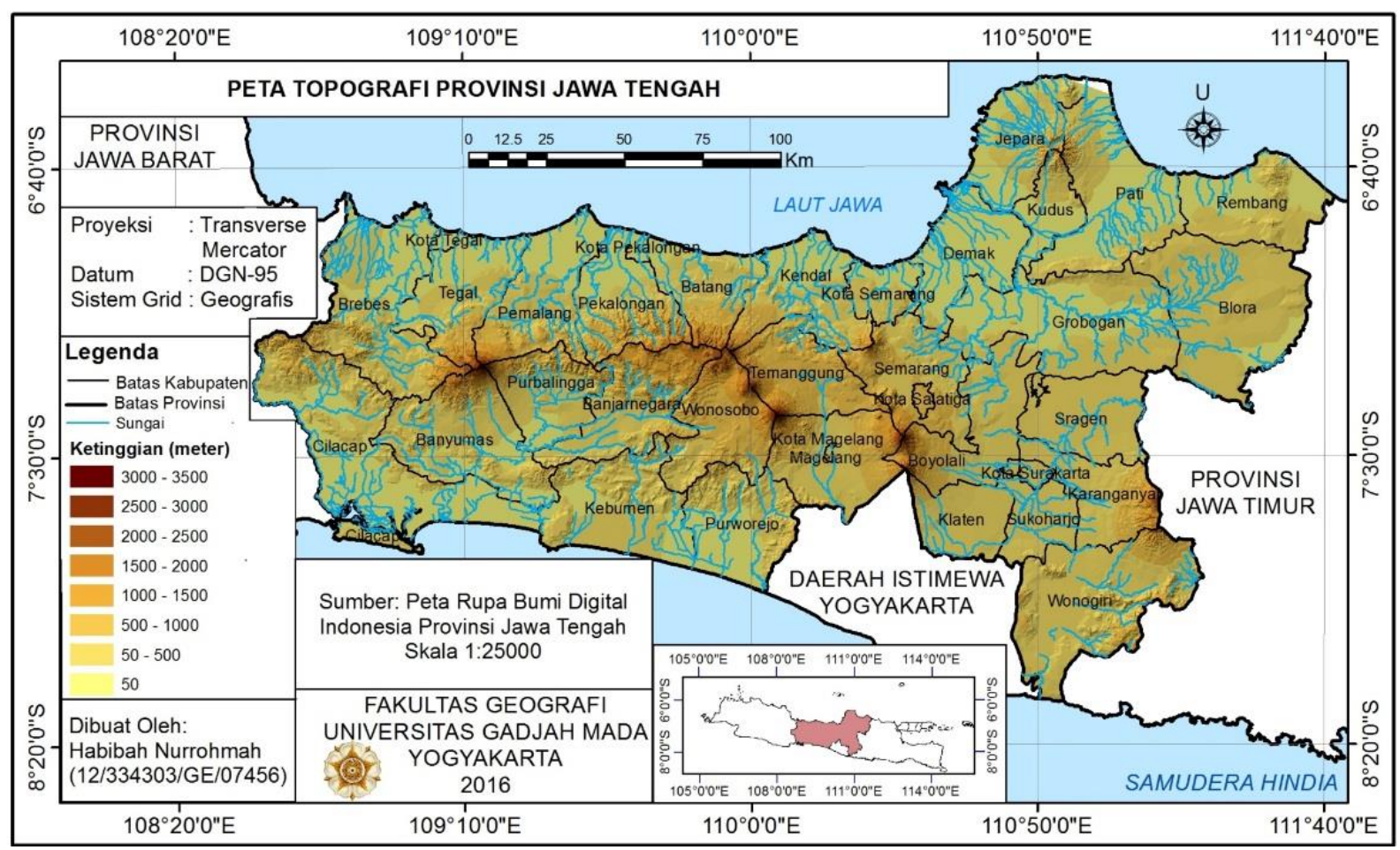

Gambar 5. Peta Topografi Provinsi Jawa Tengah

Kekeringan terjadi hampir di seluruh wilayah. Namun pada periode SeptemberNovember masih terdapat sebagian kecil wilayah di utara yang normal. Semakin ke selatan, kondisi tersebut berangsur-angsur berubah menjadi kering ekstrim. Pada periode OktoberDesember, wilayah normal meluas kearah selatan, dan kekeringan ekstrim berkurang. Hal itu membuktikan bahwa telah terjadi pergerakan angin barat laut yang kaya uap air. Oleh karena itu, semakin dekat dengan lautan yang ada di utara Pulau Jawa, kondisinya semakin mendekati normal walaupun terjadi El Nino. Peta jarak terhadap laut disajikan Gambar 6.

Kekeringan juga dapat dikaitkan dengan bentuklahan. Peta bentuklahan disajikan pada Gambar 7. Semua jenis betuklahan di Provinsi Jawa Tengah sebagian besar mengalami kekeringan pada September-Desember. Namun, pada September-November sebagian dataran aluvial di utara tergolong normal. Sementara itu, pada OktoberDesember, kondisi normal semakin meluas sampai pada bentuklahan asal proses vulkanik di zona tengah. Kekeringan pada bentuklahan asal proses vulkanik di bulan SeptemberDesember dapat mengurangi input airtanah sehingga debit mata air dan sungai di hulu dapat berkurang. Hal ini dapat mengganggu pemenuhan kebutuhan air bersih bagi masyarakat. 


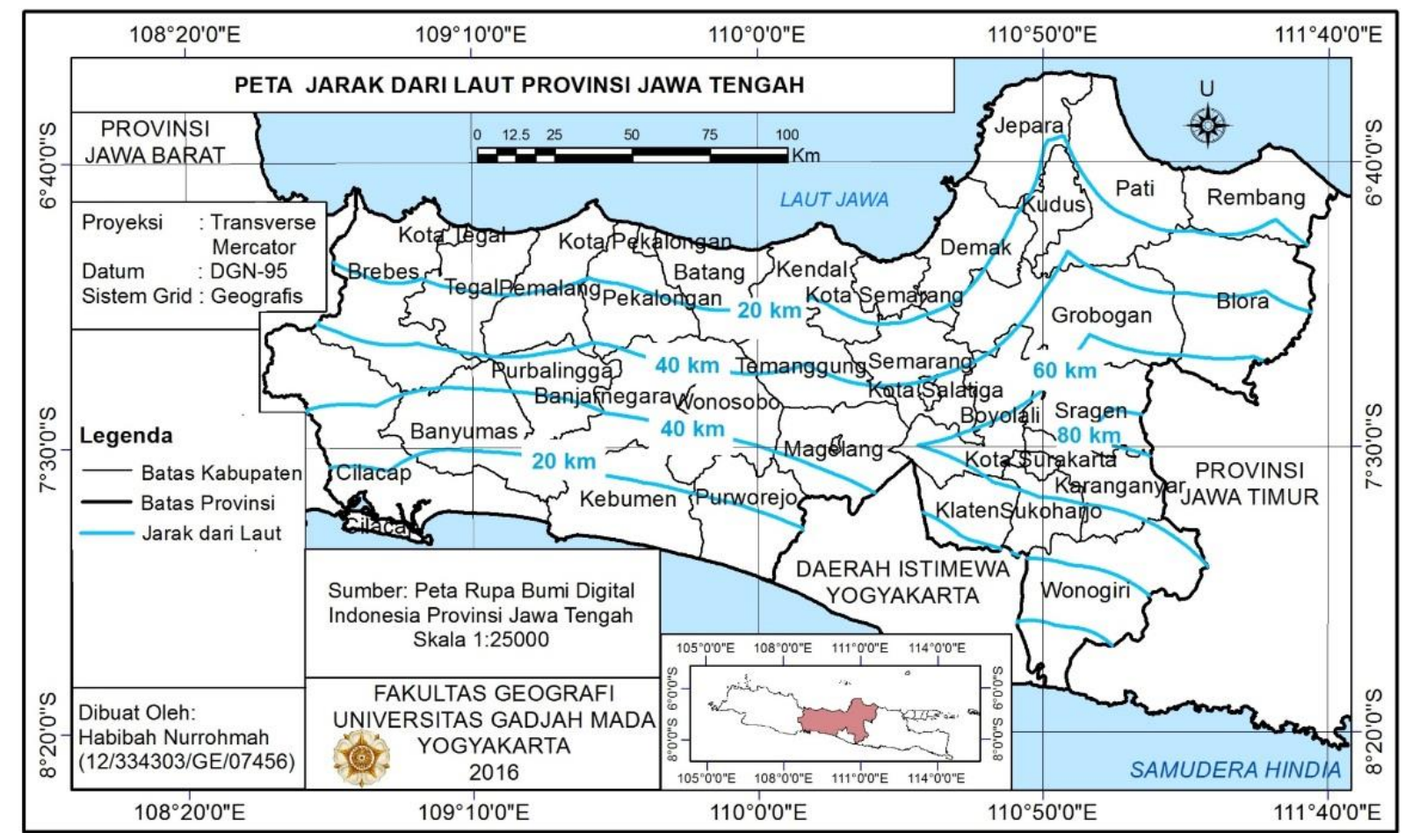

Gambar 6. Peta Jarak dari Laut Provinsi Jawa Tengah

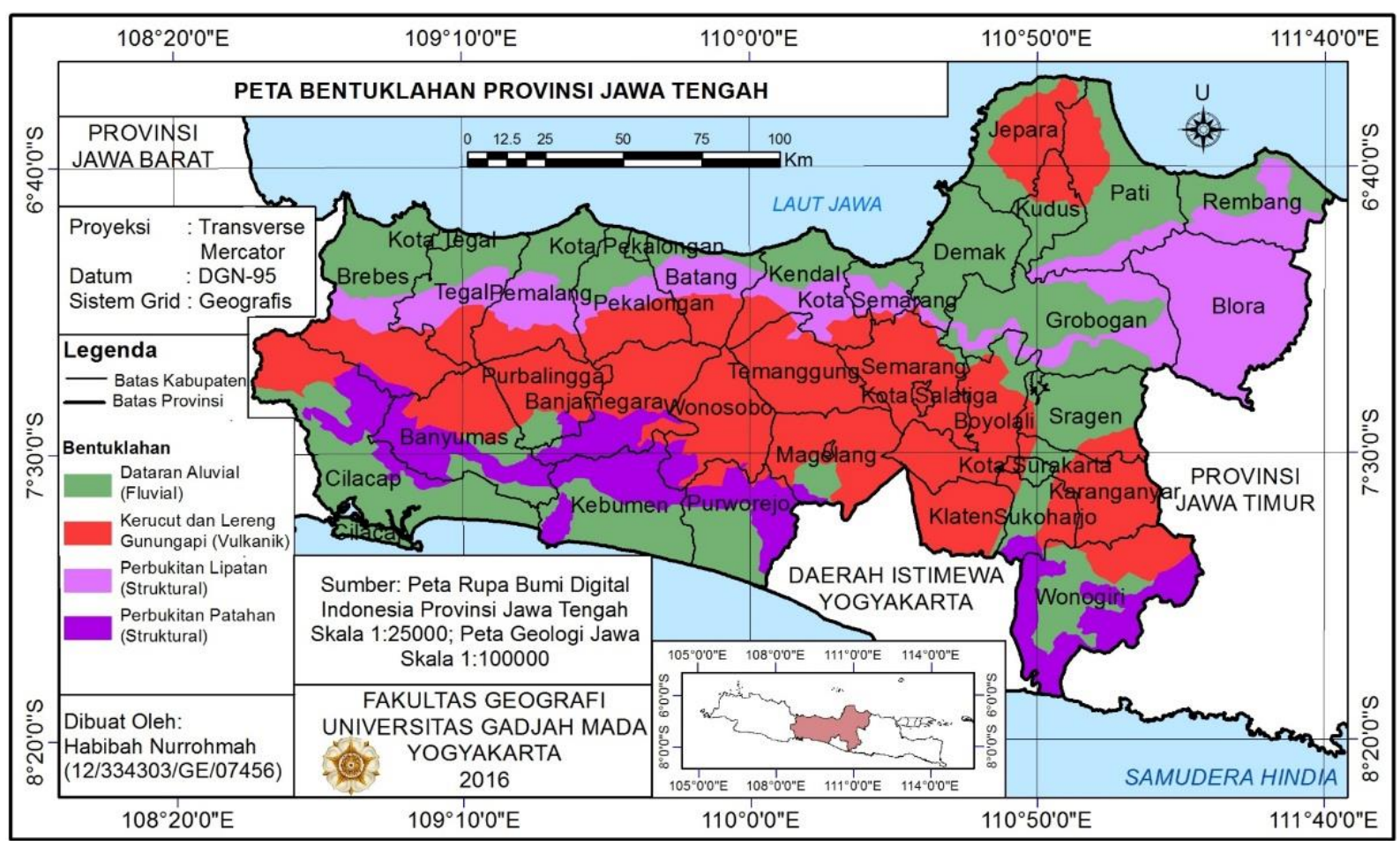

Gambar 7. Peta Bentuklahan Provinsi Jawa Tengah 


\section{Kekeringan Agustus-November 2006}

Kekeringan Agustus-November 2006 menyebabkan sebagian besar wilayah di Provinsi Jawa Tengah mengalami kekeringan seperti terlihat pada Gambar 8 dan Gambar 9. Kekeringan Agustus-Oktober didominasi golongan kering dan kekeringan SeptemberNovember didominasi golongan sangat kering. Golongan amat sangat kering terdistribusi di sisi barat dan utara pada bulan Agustus-Oktober. Kemudian, golongan tersebut meluas ke selatan dan timur, tetapi kekeringan yang awalnya di barat bergerak ke barat daya pada September-November.

Distribusi kekeringan dipengaruhi faktor lingkungan seperti topografi, bentuklahan, dan jarak dari laut. Topografi terjal pada bentuklahan asal proses vulkanik mengalami kekeringan dan berlangsung selama Agustus-November sehingga dapat mengurangi imbuhan airtanah. Angin yang kaya uap air bertiup dari barat laut pada bulan DesemberFebruari. Oleh karena itu, zona normal pada bulan Agustus-Oktober semakin meluas ke tenggara pada bulan September-November.

\section{Kekeringan Mei-Juli 1994}

Kekeringan bulan Mei-Juli 1994 menyebabkan sebagian besar wilayah di Provinsi Jawa Tengah mengalami kekeringan (Gambar 10). Golongan yang paling dominan adalah sangat kering $\left(11.150,78 \mathrm{~km}^{2}\right)$. Golongan amat sangat kering terdistribusi di tenggara dan barat laut. Sementara itu, golongan sangat kering dan kering terdistribusi hampir merata.

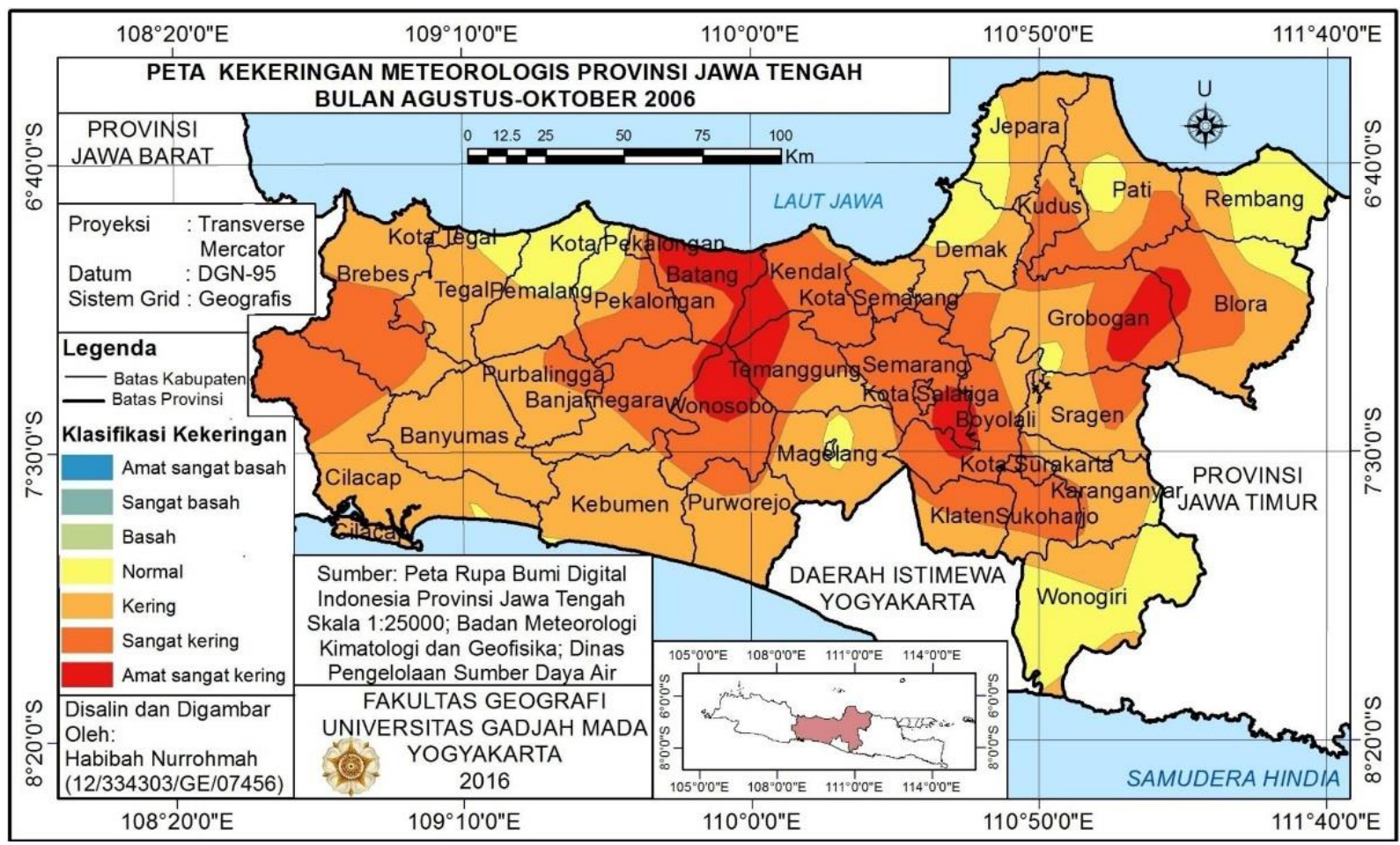

Gambar 8. Peta Kekeringan Meteorologis Provinsi Jawa Tengah Bulan Agustus-Oktober 2006 


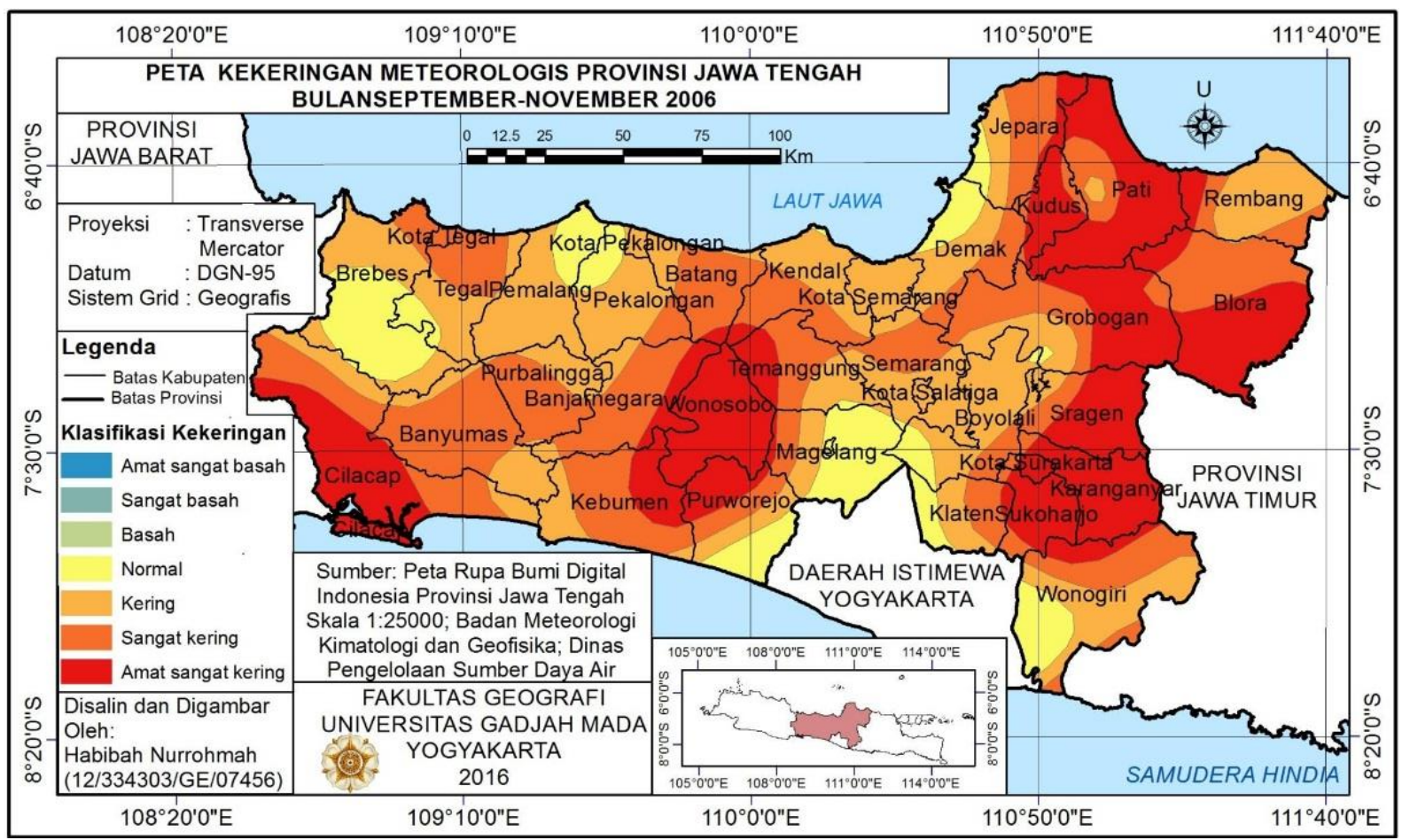

Gambar 9. Peta Kekeringan Meteorologis Provinsi Jawa Tengah Bulan SeptemberNovember 2006

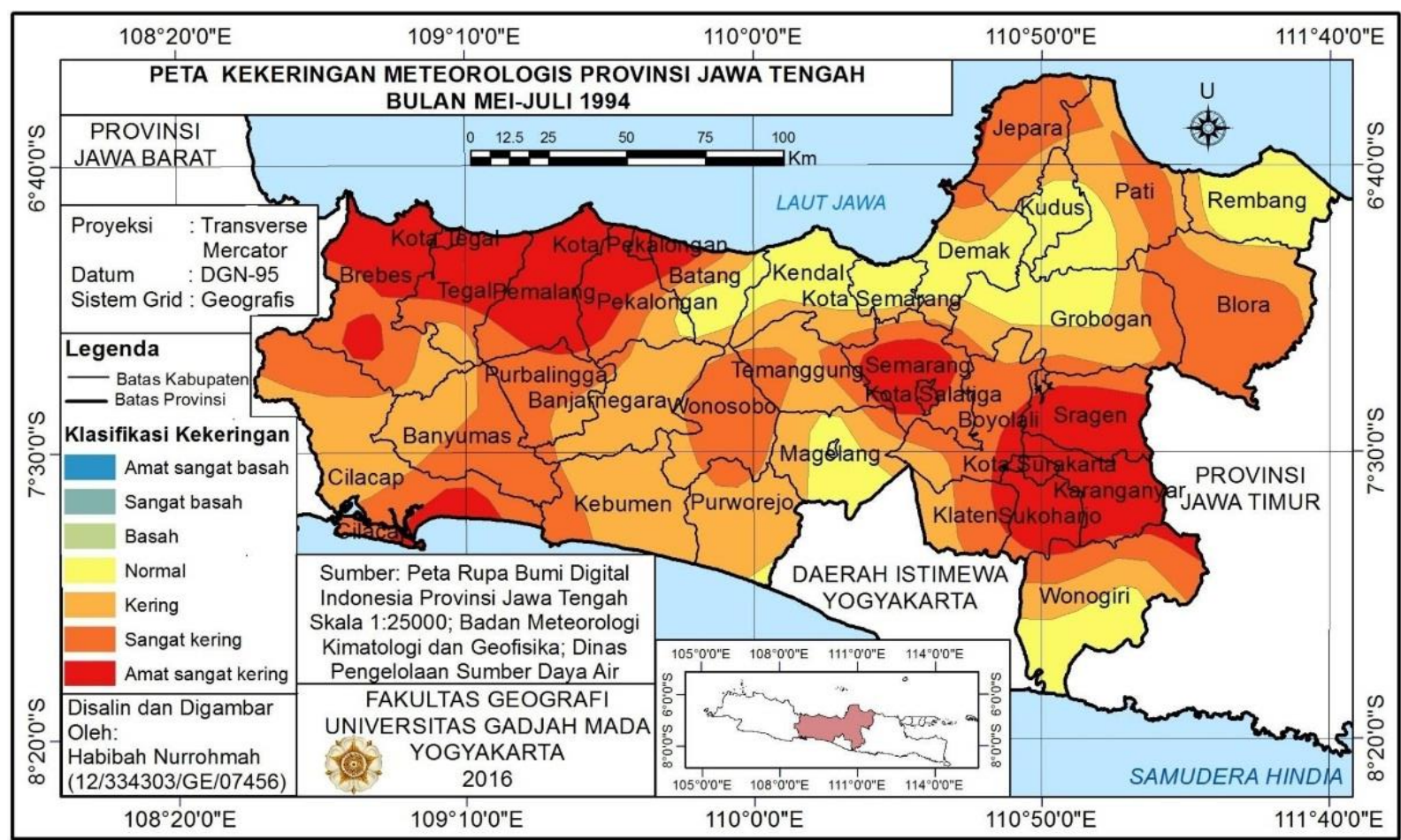

Gambar 10. Peta Kekeringan Meteorologis Provinsi Jawa Tengah Bulan Mei-Juli 1994 
Kekeringan dipengaruhi oleh jarak suatu wilayah terhadap laut. Semakin jauh jarak suatu wilayah dari laut, dampak terhadap potensi kekeringan semakin besar. Kekeringan yang terjadi pada bulan Mei-Juli menunjukkan pengaruh faktor tersebut. Bulan Mei-Juli merupakan periode ketika angin yang miskin uap air bergerak dari tenggara. Pada periode ini, wilayah di selatan dan tenggara memiliki kondisi kekeringan yang tergolong kering dan sangat kering. Sementara itu, di zona tengah dan utara yang kondisi anginnya sudah semakin miskin uap air terjadi kekeringan ekstrim. Namun demikian, terdapat pula wilayah di utara yang tergolong normal karena bulan Mei merupakan bulan peralihan dan pergerakan angin yang benar-benar bergerak dari tenggara terjadi pada Juni-Agustus (Tjasyono, 2004).

\section{Kekeringan Ekstrim}

Kekeringan ekstrim merupakan golongan kekeringan yang amat sangat kering. Kekeringan ini berdampak terhadap wilayah yang luas. Berdasarkan analisis data tahun 1981-2010, kekeringan ekstrim dapat mencapai luas 13.435,97 km². Kekeringan ekstrim terluas itu terjadi pada September-November 1997. Dari waktu ke waktu luas kekeringan ekstrim bervariasi. Tabel 4 menunjukkan peringkat 5 teratas dari luas kekeringan ekstrim yang terjadi selama periode tersebut.

Tabel 4. Kekeringan Ekstrim Tiga Bulanan Tahun 1981-2010 di Provinsi Jawa Tengah

\begin{tabular}{|l|l|l|l|}
\hline No & \multicolumn{1}{|c|}{ Tahun } & \multicolumn{1}{|c|}{ Bulan } & $\begin{array}{c}\text { Luas Kekeringan } \\
(\mathrm{km} 2)\end{array}$ \\
\hline 1 & 1997 & September-November & 13435.97 \\
\hline 2 & 2006 & September-November & 9609.13 \\
\hline 3 & $2006 / 2007$ & November-Januari & 8987.15 \\
\hline 4 & 1994 & Mei-Juli & 6579.90 \\
\hline 5 & 1982 & September-November & 6253.84 \\
\hline
\end{tabular}

El Nino merupakan faktor yang berpengaruh cukup kuat terhadap kekeringan ekstrim. Hasil analisis menunjukkan lima besar kekeringan ekstrim terluas selalu terjadi bersamaan dengan El Nino (Bureau of Meteorology Australia, 2015). Namun demikian, ternyata tidak semua kekeringan ekstrim diikuti El Nino kuat. Kekeringan ekstrim yang berada di peringkat 2 dan 3 hanya dipengaruhi El Nino lemah. Kondisi tersebut menunjukkan bahwa El Nino bukanlah satu-satunya faktor yang mempengaruhi kekeringan.

\section{Kekeringan Ekstrim September-November 1997}

Kekeringan September-Desember 1997 termasuk kekeringan ekstrim 5 besar terluas yang terjadi selama periode 1981-2010. Kekeringan ekstrim mencapai luas wilayah 13.436 $\mathrm{km}^{2}$ (39\% wilayah Provinsi Jawa Tengah). Kekeringan ekstrim tersebut terdistribusi merata dan mendominasi wilayah Provinsi Jawa Tengah seperti terlihat pada Gambar 11. Dilihat 
dari persebarannya terhadap topografi, kekeringan ekstrim sebagian besar terjadi di wilayah bertopografi landai yaitu di ujung utara dan selatan. Sisi utara dan selatan tersebut didominasi oleh bentuklahan asal proses fluvial yang memiliki airtanah dangkal dan banyak muara sungai. Walaupun wilayah di sisi utara dan selatan tersebut dekat sumber air dari laut, kekeringan ekstrim tetap dialami oleh wilayah tersebut karena bulan SeptemberNovember merupakan bulan peralihan arah angin tenggara dan barat laut.

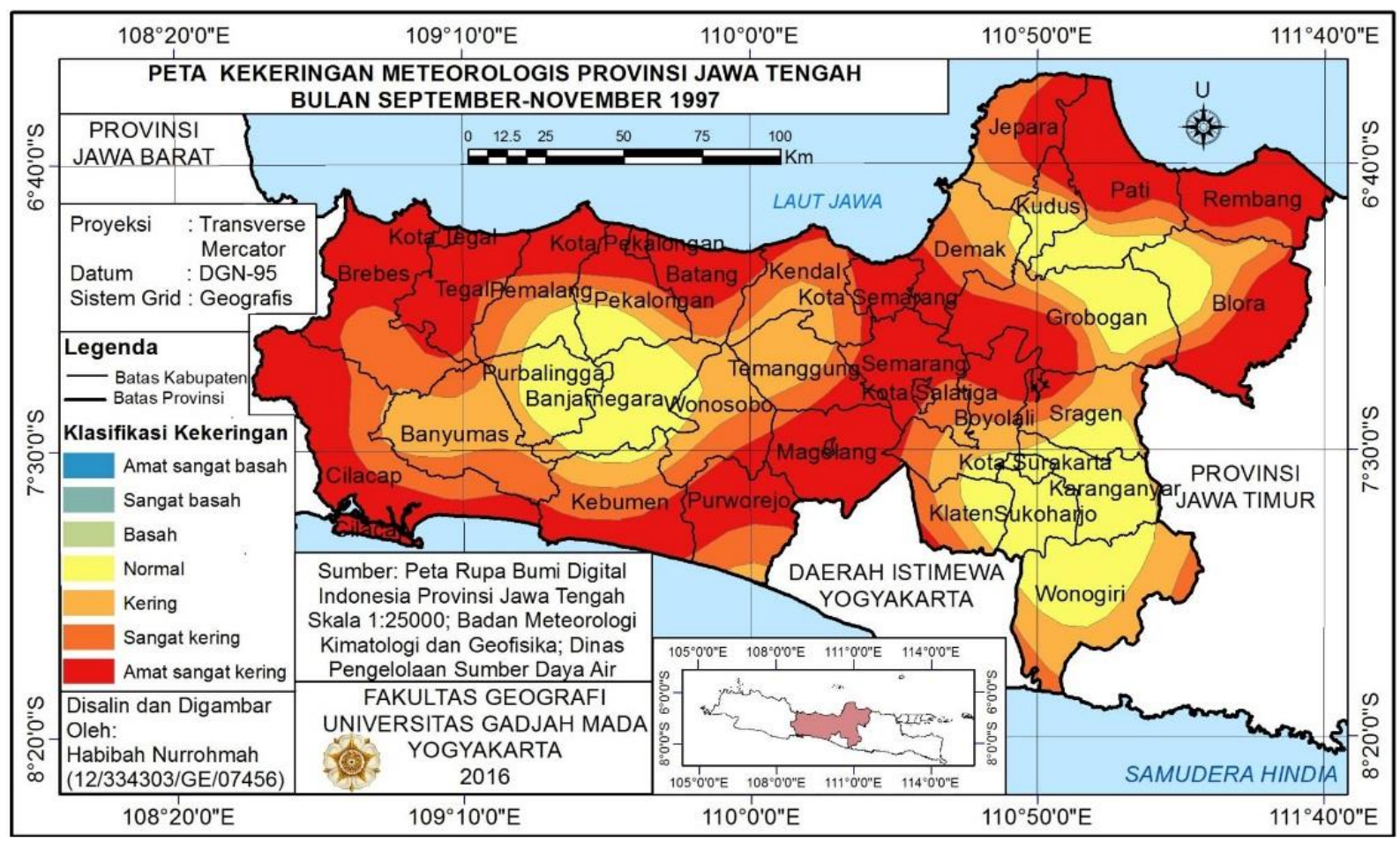

Gambar 11. Peta Kekeringan Meteorologis Provinsi Jawa Tengah Bulan SeptemberNovember 1997

\section{Kekeringan Ekstrim November-Januari 2006/2007}

Pada periode November-Januari 2006/2007, luas kekeringan ekstrim 8.987,15 km², atau mencapai 26 persen dari luas keseluruhan wilayah Provinsi Jawa Tengah. Kekeringan ekstrim tersebut terdistribusi merata dan mendominasi wilayah Provinsi Jawa Tengah seperti terlihat pada Gambar 12. Diantara yang mengalami kekeringan terdapat pula wilayah dengan kondisi normal, namun luasnya tidak terlalu signifikan. Sementara itu wilayah basah tidak dijumpai.

Kekeringan ekstrim November-Januari terjadi pada topografi terjal di sisi tengah serta topografi landai di sisi utara dan selatan. Walaupun demikian, wilayah di utara, khususnya di sekitar Kota Semarang memiliki kondisi kekeringan yang tidak terlalu parah karena dipengaruhi angin barat yang kaya uap air. Kabupaten Banyumas dan Kabupaten Wonosobo merupakan wilayah yang mengalami kekeringan ekstrim karena di sebelah utaranya terdapat topografi terjal yang menghalangi pergerakan angin barat. 


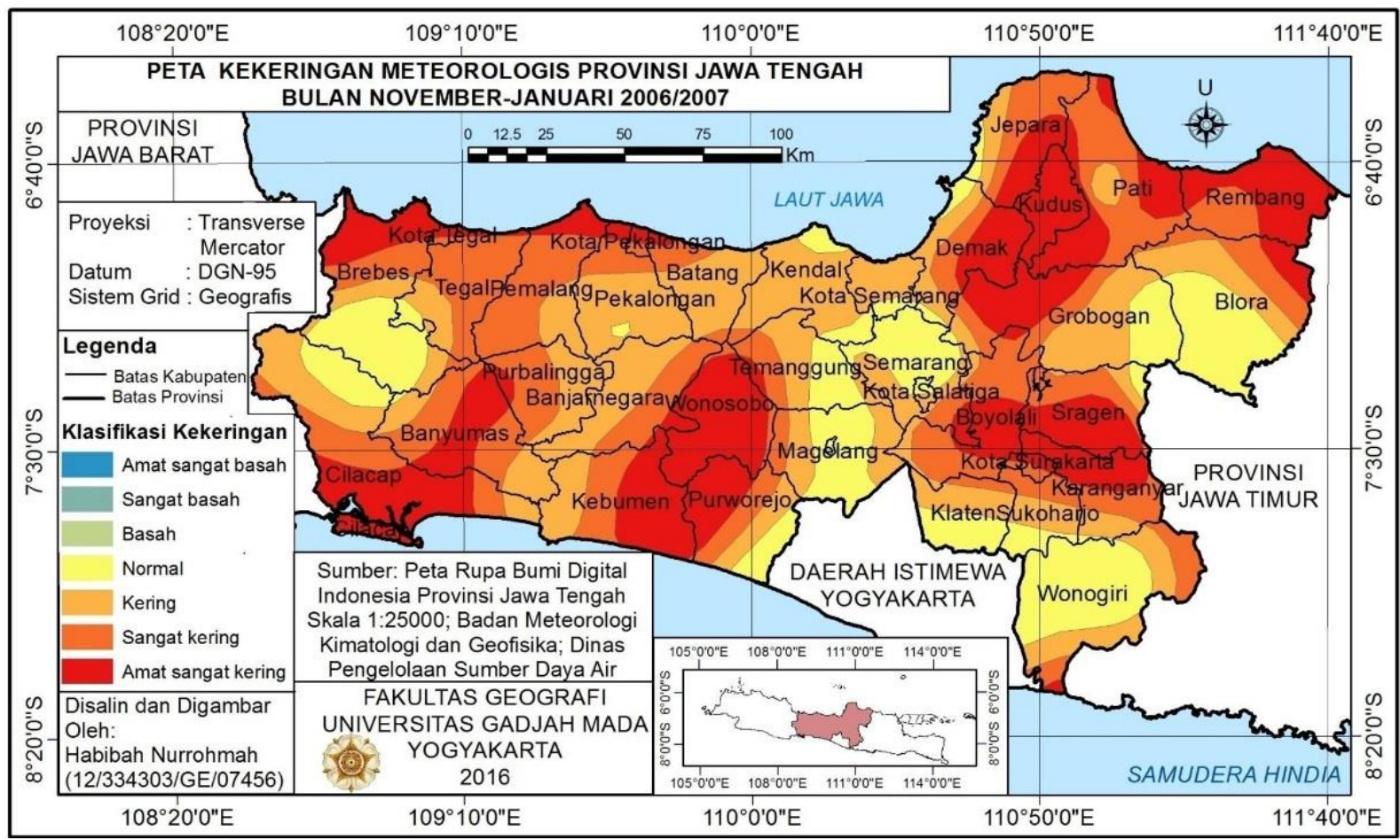

Gambar 12. Peta Kekeringan Meteorologis Provinsi Jawa Tengah Bulan November-Januari 2006/2007

Kekeringan ekstrim terjadi pada semua jenis bentuklahan yang ada di wilayah tersebut yaitu bentuklahan asal proses vulkanik, fluvial, dan struktural. Kekeringan ekstrim yang terjadi pada bentuklahan asal proses struktural dapat menimbulkan dampak yang paling besar terhadap kehidupan masyarakat. Hal ini disebabkan oleh karena masyarakat memanfaatkan mata air yang muncul dari rekahan untuk memenuhi kebutuhan air, sementara itu pengeboran air sulit dilakukan karena airtanahnya dalam. Ketika kekeringan ekstrim terjadi, imbuhan airtanah berkurang sehingga berdampak pada debit mata air yang juga berkurang.

Kekeringan ekstrim mengancam wilayah di Provinsi Jawa Tengah yang penggunaan lahannya didominasi sawah dan perkebunan. Sawah merupakan bentuk penggunaan lahan yang berpotensi terdampak kekeringan lebih besar, terutama sawah tadah hujan. Walaupun lahan sawah di Provinsi Jawa Tengah terancam oleh kekeringan ekstrim, keberadaan jaringan sungai yang kerapatan alirannya cukup tinggi dapat dimanfaakan untuk pengairan sebagai salah satu solusi menghadapi permasalahan tersebut. Untuk itu diperlukan manajemen sumberdaya air yang baik agar kebutuhan air tetap dapat terpenuhi walau terjadi kekeringan ekstrim.

\section{SIMPULAN}

Kekeringan meteorologis di Provinsi Jawa Tengah terjadi setiap tahun (1981-2010). Dari waktu ke waktu wilayah yang mengalami kekeringan cenderung berubah-ubah, 
demikian pula luas wilayah yang terdampak juga mengalami perubahan. Kekeringan terluas terjadi pada bulan September-November 1982 di 96\% wilayah Provinsi Jawa Tengah. Sementara itu, 4\% lainnya merupakan wilayah golongan normal yang berada di sebagian Kabupaten Brebes, Kabupaten Pemalang, dan Kabupaten Kudus. Kekeringan ekstrim (golongan amat sangat kering) terluas terjadi pada bulan Setember-November 1997 di 39\% wilayah Provinsi Jawa Tengah dengan pola membulat serta mengelilingi pusat-pusat wilayah normal di sekitar Kabupaten Banjarnegara, Kabupaten Wonogiri, dan Kabupaten Pati. Terdapat beberapa faktor lingkungan yang mempengaruhi distribusi spasial kekeringan di Provinsi Jawa Tengah antara lain topografi, jarak terhadap laut, dan bentuklahan.

\section{UCAPAN TERIMA KASIH}

Dalam kesempatan ini penulis mengucapkan terima kasih yang sebesar-besarnya kepada berbagai pihak yang telah membantu dalam proses penelitian, baik dalam pengumpulan data maupun analisis data, sehingga tulisan ini dapat terselesaikan dengan baik.

\section{DAFTAR PUSTAKA}

Badan Meteorologi Klimatologi dan Geofisika. 2012. Analisis Tingkat Kekeringan dan Kebasahan (Bulan Pebruari, Maret, dan april 2012 Jawa Timur). Malang: Stasiun Klimatologi Karangploso, Badan Meteorologi Klimatologi dan Geofisika.

Badan Nasional Penanggulangan Bencana. 2015. Data dan informasi bencana Indonesia. Diterima 25 Juni 2015, dari http://dibi.bnpb.go.id/

Bureau of Meteorology Australia. (2015). Southern Oscillation Index archives 1876 to present. Diterima 22 Juni 2015, dari http://www.bom.gov.au/

Kirono, D. G. C. dan Partridge, I. J. 2002. Iklim dan SOI. Dalam I. J. Partridge dan M. Ma'shum (Editor), Kapan hujan turun? Dampak osilasi selatan dan El Nino di Indonesia (hal. 1825). Brisbane: Publishing Services, DPI.

Kumar, M. N., Murthy, C. S., Sai, M. V. R. S., Roy, P. S. 2009. On the Use of Standardized Precipitation Index (SPI) for Drought Intensity Assessment. Meteorological Application, 16(3), hal 381-389.

Nugroho, S. P. 2001. Prediksi Kekeringan Pengaruh El Nino Tahun 2001-2002 dan Pemanfaatan Teknologi Modifikasi Cuaca untuk Mengantisipasinya. Jurnal Sains \& Teknologi Modifikasi Cuaca, 2 (1), hal. 75-80.

McKee, T. B., Doesken, N. J., dan Kleist, J. 1993. The Relationship of Drought Frequency and Duration to Time Scales, Dalam: Conference on Applied Climatology, diedit oleh: Department of Atmospheric Science - Colorado State University, Anaheim California.

Palmer, W. C. 1965. Meteorological Drought. Washington D.C.: United States Government Printing Office.

Pasaribu, J. M. dan Haryani, N. S. 2012. Perbandingan Teknik Interpolasi DEM SRTM dengan Metode Inverse Distance Weighted (IDW), Natural Neighbor dan Spline (Comparison 
of DEM SRTM Interpolation Techniques Using Inverse Distance Weighted (IDW), Natural Neighbor and Spline Method). Jurnal Penginderaan Jauh, 9 (2), hal. 126-139. Rijanta, R., Hizbaron, D. R., dan Baiquni, M. 2014. Modal Sosial dalam Manajemen Bencana. Yogyakarta: Gadjah Mada University Press.

Sugiyono. 2007. Metode Penelitian Administrasi. Bandung: Alfabeta.

Tjasyono, B. H. K. 2004. Klimatologi Edisi Kedua. Bandung: Penerbit ITB.

World Meteorological Organization. 2012. Standardized Precipitation Index User Guide (WMO-No. 1090). Geneva: World Meteorological Organization. 